\title{
Synthesis and Structural Study of Triphenylbismuth Bis (Salicylate)
}

\author{
Kheira Feham $^{1}$, Abdelkarim Benkadari ${ }^{2}$, Abdelkader Chouaih ${ }^{2 *}$, Abdellah Miloudi ${ }^{1,3}$, \\ Gérard Boyer $^{4}$, Douniazed El Abed ${ }^{1}$ \\ ${ }^{1}$ Laboratoire de Chimie Fine (LCF), Université d'Oran, Es-Senia, Algérie \\ ${ }^{2}$ Laboratoire SEA2M, Université de Mostaganem, Mostaganem, Algérie \\ ${ }^{3}$ Département de Physique-Chimie, ENSET d'Oran, Oran, Algérie \\ ${ }^{4}$ Laboratoire HIT, Université Paul Cezanne, Marseille, France \\ Email: "achouaih@gmail.com
}

Received October 29, 2012; revised December 5, 2012; accepted December 18, 2012

\begin{abstract}
The crystal of triphenylbismuth bis (Salicylate) pentavalent was synthesized from the reaction of triphenylbismuth dichloride with salicylic acid dissolved in methylene chloride at room temperature. The molecular and crystal structures of triphenylbismuth bis (Salicylate) were determined by X-ray diffraction analysis. This compound crystallizes in the triclinic space group $P \overline{1}$ with crystallographic parameters: $a=11.2937$ (3) $\AA, b=14.6516$ (3) $\AA, c=17.8253$ (4) $\AA, \alpha$ $=78.2958(7)^{\circ}, \beta=76.232(6)^{\circ}, \gamma=85.351(6)^{\circ}, \mu=6.332 \mathrm{~mm}, V=2803.59$ (11) $\AA, Z=2, D c=1.693 \mathrm{~g} / \mathrm{cm}$, $F(000)=1392, T=293(2) \mathrm{K}$. The final residual factor is 0.0602 for 5806 reflexions with $I>2 \sigma(I)$. The bismuth atom of the compound has a distorted trigonal-bipyramidal configuration.
\end{abstract}

Keywords: Organobismuth; Structure; X-Ray Diffraction; Salicylate; Synthesis

\section{Introduction}

Bismuth is nontoxic and relatively cheap, and bismuth compounds have been widely used in catalysis and organic synthesis [1]. Inorganic bismuth compounds such as bismuth halides have been used as Lewis acid catalysts in a number of organic reactions [1-5]. However, the utilization of organobismuth compounds trivalent and pentavalent for organic synthesis is rarely reported partly due to the unstable nature of the Bi-C bonds $[6,7]$. Recent developments show that the incorporation of a bulky substituent in pentavalent organobismuth complex can result of organobismuth compounds that have stable $\mathrm{Bi}-\mathrm{C}$ bonds [8-10]. In our research group, we have been working on the synthesis of stable pentavalent organobismuth compounds. In previous works we have synthesized organobismuth compounds such as pentavalent triphenylbismuth dichloride, triphenylbismuth diacetate and triphenylbismuth bis (thiophene carboxylate) $[7,11]$. In this work, we report synthesis and structure determination of the organobismuth compound triphenylbismuth bis (salicylate), I, where I is the pentavalent complex, bulky and more stable at room temperature.

${ }^{*}$ Corresponding author.

\section{Materials and Methods}

\subsection{Synthesis}

The compound triphenylbismuth bis (salicylate) I was prepared from the triphenyl dichloride and salicylic acid in solution of methylene chloride. The mixture is heated to react for one hour of stirring. At the end of the reaction, the mixture is removed and then recrystallized from dichloromethane/pentane (1.1) [12] (Scheme 1).

The obtained compound has the empirical formula $\mathrm{C}_{32} \mathrm{H}_{25} \mathrm{BiO}_{6}$ containing an $\mathrm{OH}$ and carboxylate groups that were chosen for our investigation for the following considerations: 1) the hydroxyl group can act as both proton acceptor to promote the formation of intermolecular hydrogen bond; 2) the oxygen atoms of the car-
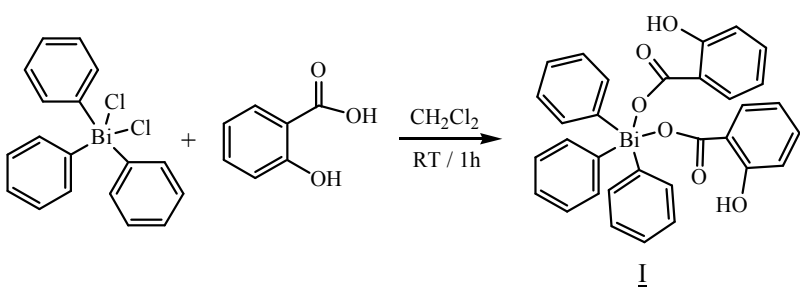

Scheme 1. The synthetic route of the triphenylbismuth bis (salicylate) compound, I. 
bismuth (V) centre, hence it could act as a proton acbonyl of carboxylate ligand is weakly associated with theceptor and participate in the formation of hydrogen bonds; 3) The oxygen atom of the carboxylate links to the central atom of bismuth, forming a stable coordination bond. The resulting compound is studied using $\mathrm{X}$-ray diffraction to obtain molecular crystal structure.

\subsection{Single Crystal X-Ray Analysis}

The crystal structure of I was determined by single crystal X-ray diffraction method. X-ray data were collected at room temperature $(293 \mathrm{~K})$ on a Kappa CCD diffractometer (Bruker Nonius, 1998) [13] using $\mathrm{MoK}_{\alpha}$ radiation ( $k=0.71073 \AA$ ), at a voltage of $50 \mathrm{kV}$ and current of 20 $\mathrm{mA}$. Cell parameters were obtained from refinement of 25 reflections collected from a random searching. Data reduction was performed with Denzo and Scalepack software [14]. Data obtained were processed with the WinGX integrated system software package for single crystal X-ray diffraction data solution, refinement and analysis [15]. The crystal structure was solved by direct methods and was refined by full-matrix least-squares refinement on $\mathrm{F}^{2}$ using the software package SHELX-97 [16]. Molecular graphics were done with ORTEP-3 [17]. In the absence of significant anomalous scattering effects Friedel pairs have been merged. The crystal data and structure refinement details are listed in Table $\mathbf{1 .}$

\section{Results and Discussion}

\subsection{Bond Length and Angles}

In Figure 1, the central bismuth-containing part exhibits a distorted pseudo-trigonal-bipyramidal structure.

The average values of bond distances and angles in different aryl rings are in agreement with the literature

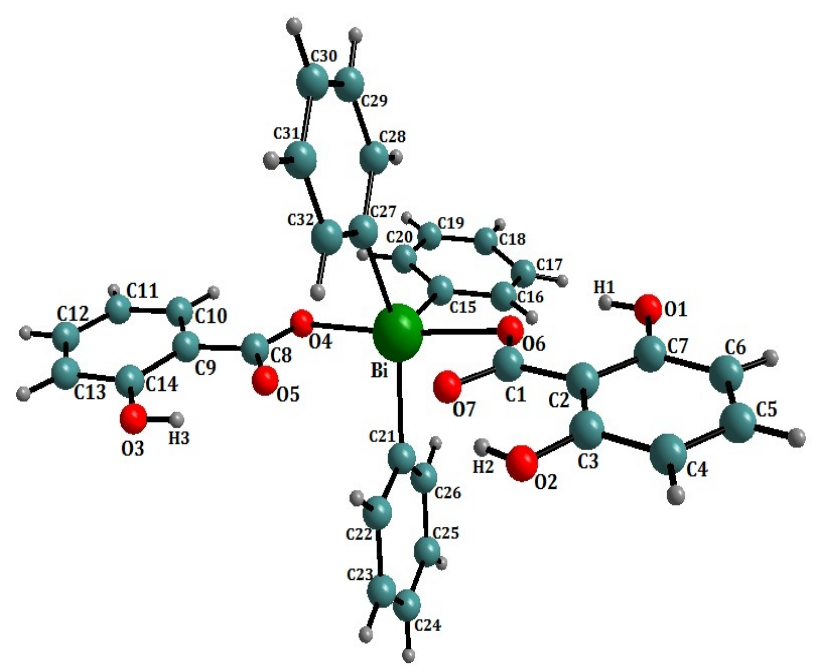

Figure 1. Perspective view of the molecule of triphenylbismuth bis (salicylate), I showing the labelling scheme.
Table 1. Crystal data and structure refinement details for $\mathrm{C}_{32} \mathrm{H}_{25} \mathrm{BiO}_{6}$ compound.

\begin{tabular}{|c|c|}
\hline Chemical formula & $\mathrm{C}_{32} \mathrm{H}_{25} \mathrm{BiO}_{6}$ \\
\hline CCDC deposit & 737,905 \\
\hline Colour & colourless \\
\hline Crystal dimensions (mm) & $0.15 \times 0.10 \times 0.10$ \\
\hline Formula weight & 1429 \\
\hline Crystal system & Triclinic \\
\hline Space group & $P \overline{1}$ \\
\hline \multicolumn{2}{|l|}{ Unit cell dimensions } \\
\hline$a(\AA)$ & $11.2937(3)$ \\
\hline$b(\AA)$ & $14.6516(3)$ \\
\hline$c(\AA)$ & $17.8253(4)$ \\
\hline$\alpha\left({ }^{\circ}\right)$ & $78.2958(7)$ \\
\hline$\beta\left(^{\circ}\right)$ & $76.232(6)$ \\
\hline$\gamma\left({ }^{\circ}\right)$ & $85.351(6)$ \\
\hline Cell volume $\left(\AA^{3}\right)$ & $2803.59(11)$ \\
\hline$Z$ & 2 \\
\hline Temperature $(\mathrm{K})$ & $293(2)$ \\
\hline Density $\left(\mathrm{g} / \mathrm{cm}^{3}\right)$ & 1.693 \\
\hline Absorption coefficient $\left(\mathrm{mm}^{-1}\right)$ & 6.332 \\
\hline Diffractometer & Kappa CCD \\
\hline Radiation, $\lambda(\AA)$ & $\mathrm{MoK}_{\alpha}, 0.71073$ \\
\hline Theta min-max $\left({ }^{\circ}\right)$ & $1.68-27.89$ \\
\hline Reflections collected/unique & $32748 / 12722$ \\
\hline Range of $h, k, l$ & $\begin{array}{l}-13 \leq h \leq 14, \\
-18 \leq k \leq 19 \\
0 \leq l \leq 23\end{array}$ \\
\hline Absorption correction & Sortav (Blessing, 1997) \\
\hline Data/restraints/parameters & $5806 / 0 / 712$ \\
\hline Goodness of fit on $F^{2}$ & 0.857 \\
\hline Final $R$ indices $R\left[F^{2}>2 \sigma\left(F^{2}\right)\right]$ & 0.0602 \\
\hline$R$ indices (all data) & 0.1564 \\
\hline
\end{tabular}

values [18]. The bond distances and valence angles of molecule $\mathbf{I}$ are shown in Table 2.

According to X-ray diffraction data of compound $\mathbf{I}$ and as shown in Figure 2, Bi atom has distorted trigonal-bipyramidal coordination with oxygen atoms in apical positions. The $\mathrm{O}(1)$ and $\mathrm{O}(4)$ atoms are located at the apical positions and the $C(21), C(27)$ and $C(15)$ atoms are at the equatorial positions. The sum of angles in 
Table 2. Bond distances and bond angles for non-hydrogen atoms (e.s.d.'s are given in parenthesis).

\begin{tabular}{|c|c|c|c|}
\hline Bond distance $(\AA)$ & & Bond angles $\left({ }^{\circ}\right)$ & \\
\hline Bi-O1 & $2.303(6)$ & O1-Bi-O4 & $172.6(2)$ \\
\hline Bi-O4 & $2.313(6)$ & O1-Bi-C15 & $93.4(3)$ \\
\hline $\mathrm{Bi}-\mathrm{C} 15$ & $2.215(9)$ & O1-Bi-C21 & $87.8(3)$ \\
\hline $\mathrm{Bi}-\mathrm{C} 21$ & $2.238(8)$ & $\mathrm{O} 1-\mathrm{Bi}-\mathrm{C} 27$ & $87.5(3)$ \\
\hline $\mathrm{Bi}-\mathrm{C} 27$ & $2.200(9)$ & O4-Bi-C15 & $91.9(3)$ \\
\hline $\mathrm{O} 1-\mathrm{C} 1$ & $1.303(11)$ & O4-Bi-C21 & $86.0(3)$ \\
\hline $\mathrm{O} 2-\mathrm{C} 1$ & $1.246(12)$ & $\mathrm{O} 4-\mathrm{Bi}-\mathrm{C} 27$ & $91.1(3)$ \\
\hline $\mathrm{O} 3-\mathrm{C} 3$ & $1.380(14)$ & $\mathrm{C} 15-\mathrm{Bi}-\mathrm{C} 21$ & $104.1(4)$ \\
\hline $\mathrm{O} 4-\mathrm{C} 8$ & $1.289(11)$ & C15-Bi-C27 & $144.4(4)$ \\
\hline $\mathrm{O} 5-\mathrm{C} 8$ & $1.239(11)$ & C21-Bi-C27 & $111.5(4)$ \\
\hline O6-C10 & $1.358(13)$ & $\mathrm{Bi}-\mathrm{O} 1-\mathrm{C} 1$ & $105.4(6)$ \\
\hline $\mathrm{C} 1-\mathrm{C} 2$ & $1.501(14)$ & B-O4-C8 & $107.9(4)$ \\
\hline $\mathrm{C} 2-\mathrm{C} 3$ & $1.415(15)$ & $\mathrm{O} 1-\mathrm{C} 1-\mathrm{O} 2$ & $121.0(9)$ \\
\hline $\mathrm{C} 2-\mathrm{C} 7$ & $1.386(16)$ & $\mathrm{O} 1-\mathrm{C} 1-\mathrm{C} 2$ & $114.5(11)$ \\
\hline $\mathrm{C} 3-\mathrm{C} 4$ & $1.395(17)$ & $\mathrm{O} 2-\mathrm{C} 1-\mathrm{C} 2$ & $124.3(11)$ \\
\hline $\mathrm{C} 4-\mathrm{C} 5$ & $1.33(2)$ & $\mathrm{C} 1-\mathrm{C} 2-\mathrm{C} 3$ & $117.0(12)$ \\
\hline $\mathrm{C} 5-\mathrm{C} 6$ & $1.36(2)$ & $\mathrm{C} 1-\mathrm{C} 2-\mathrm{C} 7$ & $122.8(11)$ \\
\hline $\mathrm{C} 6-\mathrm{C} 7$ & $1.365(16)$ & $\mathrm{O} 3-\mathrm{C} 3-\mathrm{C} 2$ & $121.7(11)$ \\
\hline C8-C9 & $1.472(13)$ & $\mathrm{O} 3-\mathrm{C} 3-\mathrm{C} 4$ & $119.0(14)$ \\
\hline C9-C10 & $1.368(14)$ & $\mathrm{C} 2-\mathrm{C} 3-\mathrm{C} 4$ & $119.3(14)$ \\
\hline C9-C14 & $1.403(13)$ & $\mathrm{C} 3-\mathrm{C} 4-\mathrm{C} 5$ & $119.5(17)$ \\
\hline \multirow[t]{8}{*}{$\mathrm{C} 10-\mathrm{C} 11$} & $1.393(17)$ & $\mathrm{C} 4-\mathrm{C} 5-\mathrm{C} 6$ & $120.5(16)$ \\
\hline & & $\mathrm{C}-\mathrm{C} 6-\mathrm{C} 7$ & $123.9(16)$ \\
\hline & & $\mathrm{C} 2-\mathrm{C} 7-\mathrm{C} 6$ & $116.5(14)$ \\
\hline & & $\mathrm{O} 4-\mathrm{C} 8-\mathrm{O} 5$ & $120.5(9)$ \\
\hline & & $\mathrm{O} 4-\mathrm{C} 8-\mathrm{C} 9$ & $116.3(10)$ \\
\hline & & $\mathrm{O} 5-\mathrm{C} 8-\mathrm{C} 9$ & $123.2(10)$ \\
\hline & & C8-C9-C10 & $118.1(10)$ \\
\hline & & C10-C9-C14 & $119.6(10)$ \\
\hline
\end{tabular}

equatorial plan and the axial angle $\mathrm{O}-\mathrm{Bi}-\mathrm{O}$ for the title compound are $360^{\circ}\left(144.4^{\circ}, 104.1^{\circ}\right.$ and $\left.111.5^{\circ}\right)$ and $172.6^{\circ}$, respectively.

$$
w=1 /\left[\sigma^{2}\left(F o^{2}\right)+(0.0437 P)^{2}+2.0512 P\right]
$$

where

$$
P=\left(F o^{2}+2 F c^{2}\right) / 3
$$

The $\mathrm{Bi}$ atom does not almost extend from the equatorial plan as we can view in Figure 2.

However, the (Bi-C(15), Bi-C(21), Bi-C(27)) distances are (2.215 (9), $2.238(8)$ and 2.200 (9) $\AA$ ) respectively. The Bi-O(1) and Bi-O(4) distances are (2.303 (6) $\AA$ ) and (2.313 (6) $\AA$ ) respectively. We note that, from Figure 3 that the ligands of carboxylate groups are in cis-position compared to the phenyl group. In the other hand, intermolecular interaction between the bismuth atom and the two carbonyl groups forms the Van-Der-Waals bond.

The distances between valence-non-bonded $\mathrm{Bi}-\mathrm{O}(2)$ and Bi-O(5) are respectively 2.814 (4) and 2.861 (3) $\AA$ (Figure 3) which indicate that oxygen atoms are weakly coordinated with the bismuth atom and form a cis conformation together.

This conformation apparently causes significant deviation of the $\mathrm{C}-\mathrm{Bi}-\mathrm{C}$ angles from $120^{\circ}$ in the equatorial plan.

However, Figure 4 shows, in the equatorial plane, that the two aromatic rings $\mathrm{A}$ and $\mathrm{B}$ are perpendicular to

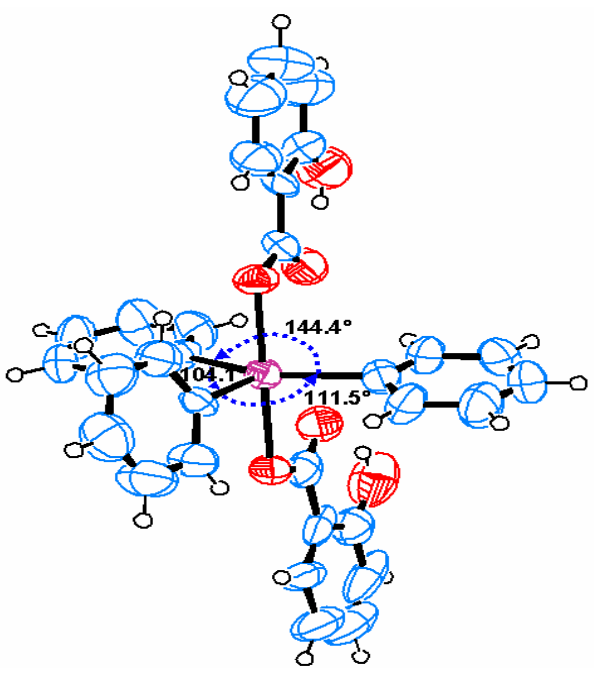

Figure 2. Three dimensional structure of compound I showing different angles in equatorial plan.

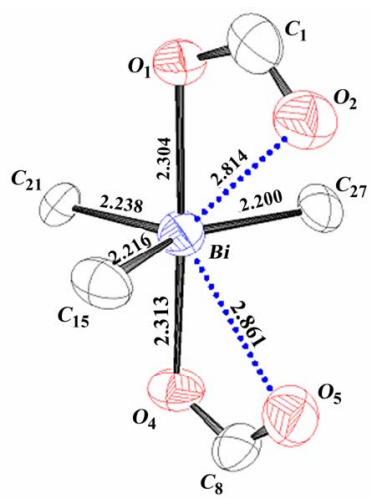

Figure 3. Bond lengths of atoms surrounding the bismuth atom. 


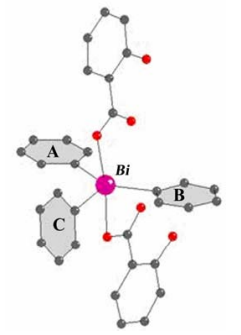

Figure 4. A, $\mathrm{B}$ and $\mathrm{C}$ rings compared to $\mathrm{Bi}-\mathrm{O}$ bond apical position. $A$ and $B$ rings are in the same plan.

$\mathrm{Bi}-\mathrm{O}$ bond while the third aromatic ring $\mathrm{C}$ is parallel to $\mathrm{Bi}-\mathrm{O}$. The axial positions are occupied by electronegative atoms and the equatorial ones by carbon atoms of the aromatic groups. The distortion of the coordination geometry at bismuth is mainly due to the restrictions imposed by the chelate rings.

The bond distances and valence angles of carbon $(\mathrm{C} 15$, $\mathrm{C} 21$ and $\mathrm{C} 27)$ and oxygen (O2 and $\mathrm{O} 4)$ atoms surrounding the bismuth central atom are shown in Figure 5.

\subsection{Dihedral Angles}

Torsion angles are reported in Table 3. We can see that, the carboxyl groups are coplanar $(\mathrm{Bi}-\mathrm{O}(1)-\mathrm{C}(1)-\mathrm{O}(2)$ and $\mathrm{Bi}-\mathrm{O}(4)-\mathrm{C}(8)-\mathrm{O}(5))$. These two dihedral angles are about $-8.01^{\circ}$ and $-1.83^{\circ}$ respectively (Table 3 ).

\subsection{Hydrogen Bonds}

The bond distance between hydrogen and carbon, hydrogen and oxygen noted X-H $(\AA)$ and the possible intramolecular interactions by hydrogen bonds noted $\mathrm{X}-\mathrm{H}$ ( $\AA)$ of molecule $\mathbf{I}$ is shown in Table 4.

These different hydrogen bonds showed in Figure $\mathbf{6}$ are responsible of the molecular packing in the unit cell.

\subsection{Crystal Packing}

Hydrogen bonds played crucial roles in the crystal packing. Figure 7 shows the presence of two molecules in the unit cell $(Z=2)$ which corresponds to the centrosymmetric triclinic space group $P 1$ with two general positions $(x, y, z)$ and $(-x,-y,-z)$.

\section{Conclusions}

The new pentavalent triphenylbismuth bis (salicylate) was synthesized with a good yield and its crystal structure was determined by X-ray diffraction analysis at room temperature. This work shows that coordination by the salicylate group is more stable, when compared to pentaphenylbismuth.

This is caused by rigidity of the ligand between the bismuth and oxygen atoms, and the presence of hydrogen bonding and the Van-Der-Waals bonding. The three-di-
Table 3. Dihedral angles in degrees with e.s.d.'s given in parenthesis.

\begin{tabular}{|c|c|}
\hline Dihedral angles $\left({ }^{\circ}\right)$ & \\
\hline O4-Bi-O1-C1 & -148.12 \\
\hline C15-Bi-O1-C1 & 75.50 \\
\hline C21-Bi-O1-C1 & 179.52 \\
\hline $\mathrm{C} 27-\mathrm{Bi}-\mathrm{O} 1-\mathrm{C} 1$ & -68.82 \\
\hline $\mathrm{O} 1-\mathrm{Bi}-\mathrm{O} 4-\mathrm{C} 8$ & 155.21 \\
\hline C15-Bi-O4-C8 & -68.34 \\
\hline C21-Bi-O4-C8 & -172.36 \\
\hline $\mathrm{C} 27-\mathrm{Bi}-\mathrm{O} 4-\mathrm{C} 8$ & 76.14 \\
\hline O1-Bi-C15-C16 & -101.51 \\
\hline O1-Bi-C15-C20 & 77.26 \\
\hline O4-Bi-C15-C16 & 83.58 \\
\hline $\mathrm{O} 4-\mathrm{Bi}-\mathrm{C} 15-\mathrm{C} 20$ & -97.65 \\
\hline C21-Bi-C15-C16 & 169.89 \\
\hline $\mathrm{C} 21-\mathrm{Bi}-\mathrm{C} 15-\mathrm{C} 20$ & -11.34 \\
\hline C27-Bi-C15-C16 & -11.01 \\
\hline C27-Bi-C15-C20 & 167.76 \\
\hline O1-Bi-C21-C22 & -165.63 \\
\hline O1-Bi-C21-C26 & 10.43 \\
\hline $\mathrm{O} 4-\mathrm{Bi}-\mathrm{C} 21-\mathrm{C} 22$ & 18.32 \\
\hline O4-Bi-C21-C26 & -165.61 \\
\hline C15-Bi-C21-C22 & -72.63 \\
\hline $\mathrm{C} 15-\mathrm{Bi}-\mathrm{C} 21-\mathrm{C} 26$ & 103.44 \\
\hline $\mathrm{C} 27-\mathrm{Bi}-\mathrm{C} 21-\mathrm{C} 22$ & 107.94 \\
\hline C27-Bi-C21-C26 & -76.00 \\
\hline O1-Bi-C27-C32 & -76.02 \\
\hline O4-Bi-C27-C28 & -85.34 \\
\hline O4-Bi-C27-C32 & 96.72 \\
\hline C21-Bi-C27-C28 & -171.43 \\
\hline C21-Bi-C27-C32 & 10.62 \\
\hline $\mathrm{Bi}-\mathrm{O} 4-\mathrm{C} 8-\mathrm{O} 5$ & -1.83 \\
\hline $\mathrm{Bi}-\mathrm{O} 4-\mathrm{C} 8-\mathrm{C} 9$ & 178.75 \\
\hline $\mathrm{O} 1-\mathrm{C} 1-\mathrm{C} 2-\mathrm{C} 3$ & 177.38 \\
\hline $\mathrm{O} 1-\mathrm{C} 1-\mathrm{C} 2-\mathrm{C} 7$ & -4.16 \\
\hline $\mathrm{O} 2-\mathrm{C} 1-\mathrm{C} 2-\mathrm{C} 3$ & 1.62 \\
\hline $\mathrm{O} 2-\mathrm{C} 1-\mathrm{C} 2-\mathrm{C} 7$ & -179.92 \\
\hline $\mathrm{C} 1-\mathrm{C} 2-\mathrm{C} 3-\mathrm{O} 3$ & 3.34 \\
\hline $\mathrm{C} 1-\mathrm{C} 2-\mathrm{C} 3-\mathrm{C} 4$ & -179.12 \\
\hline $\mathrm{C} 7-\mathrm{C} 2-\mathrm{C} 3-\mathrm{O} 3$ & -175.16 \\
\hline $\mathrm{C} 7-\mathrm{C} 2-\mathrm{C} 3-\mathrm{C} 4$ & 2.37 \\
\hline $\mathrm{C} 1-\mathrm{C} 2-\mathrm{C} 7-\mathrm{C} 6$ & 178.78 \\
\hline $\mathrm{C} 3-\mathrm{C} 2-\mathrm{C} 7-\mathrm{C} 6$ & -2.81 \\
\hline $\mathrm{O} 3-\mathrm{C} 3-\mathrm{C} 4-\mathrm{C} 5$ & 175.31 \\
\hline $\mathrm{C} 2-\mathrm{C} 3-\mathrm{C} 4-\mathrm{C} 5$ & -2.29 \\
\hline
\end{tabular}




\section{Continued}

\begin{tabular}{|c|c|}
\hline C3-C4-C5-C6 & 2.76 \\
\hline $\mathrm{C} 4-\mathrm{C} 5-\mathrm{C} 6-\mathrm{C} 7$ & -3.45 \\
\hline $\mathrm{C} 5-\mathrm{C} 6-\mathrm{C} 7-\mathrm{C} 2$ & 3.39 \\
\hline $\mathrm{O} 4-\mathrm{C} 8-\mathrm{C} 9-\mathrm{C} 10$ & -177.60 \\
\hline O4-C8-C9-C14 & 2.98 \\
\hline O5-C8-C9-C10 & 3.00 \\
\hline C8-C9-C10-O6 & 2.49 \\
\hline C8-C9-C10-C11 & -179.81 \\
\hline C14-C9-C10-O6 & -178.08 \\
\hline C14-C9-C10-C11 & -0.37 \\
\hline C8-C9-C14-C13 & -179.33 \\
\hline C10-C9-C14-C13 & 1.26 \\
\hline O6-C10-C11-C12 & 177.42 \\
\hline C9-C10-C11-C12 & -0.40 \\
\hline C10-C11-C12-C13 & 0.29 \\
\hline C11-C12-C13-C14 & 0.60 \\
\hline C12-C13-C14-C9 & -1.36 \\
\hline Bi-C15-C16-C17 & -179.16 \\
\hline C20-C15-C16-C17 & 2.17 \\
\hline Bi-C15-C20-C19 & 178.95 \\
\hline $\mathrm{C} 16-\mathrm{C} 15-\mathrm{C} 20-\mathrm{C} 19$ & -2.24 \\
\hline C15-C16-C17-C18 & -0.17 \\
\hline C16-C17-C18-C19 & -1.73 \\
\hline C17-C18-C19-C20 & 1.64 \\
\hline C18-C19-C20-C15 & 0.29 \\
\hline $\mathrm{Bi}-\mathrm{C} 21-\mathrm{C} 22-\mathrm{C} 23$ & 175.91 \\
\hline $\mathrm{C} 26-\mathrm{C} 21-\mathrm{C} 22-\mathrm{C} 23$ & -0.20 \\
\hline $\mathrm{Bi}-\mathrm{C} 21-\mathrm{C} 26-\mathrm{C} 25$ & -176.08 \\
\hline C22-C21-C26-C25 & -0.05 \\
\hline C21-C22-C23-C24 & 0.53 \\
\hline C22-C23-C24-C25 & -0.62 \\
\hline C23-C24-C25-C26 & 0.37 \\
\hline C24-C25-C26-C21 & -0.04 \\
\hline $\mathrm{Bi}-\mathrm{C} 27-\mathrm{C} 28-\mathrm{C} 29$ & 178.00 \\
\hline $\mathrm{Bi}-\mathrm{C} 27-\mathrm{C} 32-\mathrm{C} 31$ & -178.10 \\
\hline
\end{tabular}

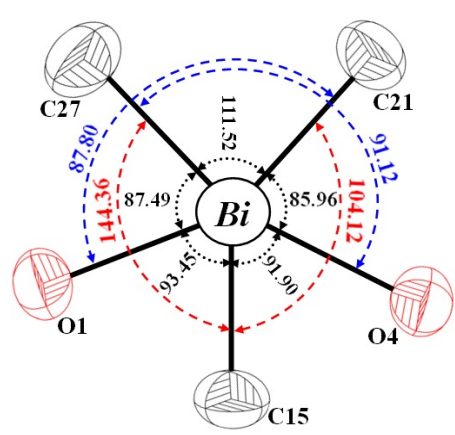

Figure 5. Bond distances and valence angles around the bismuth atom.

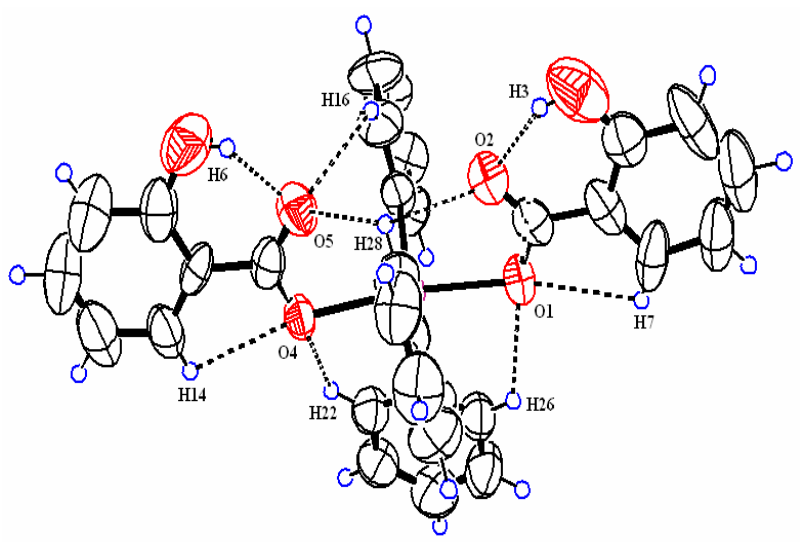

Figure 6. Hydrogen bonds representation ensuring the molecular packing in the unit cell of compound I.

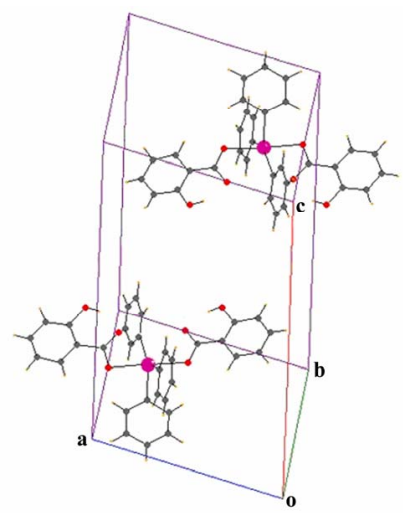

Figure 7. Molecular packing in the unit cell showing two molecules in symmetric positions $(x, y, z)$ and $(-x,-y,-z)$. Hydrogen atoms are shown as small spheres for clarity.

Table 4. Hydrogen bonds X-H and X ...H of molecule I.

\begin{tabular}{cc|cc}
\hline \multicolumn{2}{c|}{$\begin{array}{c}\text { Distance of virtual bond } \\
\mathbf{X} \cdots \mathbf{H}(\AA)\end{array}$} & \multicolumn{2}{c}{$\begin{array}{c}\text { Distance of actual bond } \\
\mathbf{X}-\mathbf{H}(\boldsymbol{\AA})\end{array}$} \\
\hline $\mathrm{H} 3 \ldots \mathrm{O} 2$ & 1.822 & $\mathrm{O} 3-\mathrm{H} 3$ & 0.820 \\
$\mathrm{H} 6 \ldots \mathrm{O} 5$ & 1.798 & $\mathrm{O} 6-\mathrm{H} 6$ & 0.820 \\
$\mathrm{H} 7 \ldots \mathrm{O} 1$ & 2.533 & $\mathrm{C} 7-\mathrm{H} 7$ & 0.929 \\
$\mathrm{H} 14 \ldots \mathrm{O} 4$ & 2.513 & $\mathrm{C} 14-\mathrm{H} 14$ & 0.930 \\
$\mathrm{H} 16 \ldots \mathrm{O} 5$ & 2.556 & $\mathrm{C} 16-\mathrm{H} 16$ & 0.931 \\
$\mathrm{H} 22 \ldots \mathrm{O} 4$ & 2.369 & $\mathrm{C} 22-\mathrm{H} 22$ & 0.930 \\
$\mathrm{H} 26 \ldots \mathrm{O} 1$ & 2.453 & $\mathrm{C} 26-\mathrm{H} 26$ & 0.929 \\
$\mathrm{H} 28 \ldots \mathrm{O} 2$ & 2.777 & $\mathrm{C} 28-\mathrm{H} 28$ & 0.930 \\
$\mathrm{H} 28 \ldots \mathrm{O} 5$ & 2.636 & & \\
\hline
\end{tabular}

bonding and the Van-Der-Waals bonding. The three-dimensional representation of the molecule shows the axial position of the two salicylate groups and the equatorial position of the three phenyls. This shows that the crystal structure of triphenylbismuth bis (Salicylate) pentavalent has a shape distorted trigonal-bipyramid. 


\section{REFERENCES}

[1] In: H. Suzuki and Y. Matano, Eds., Organobismuth Chemistry, Elsevier, Amsterdam, 2001.

[2] In: H. Yamamoto and H. Ishihara, Eds., Acid Catalysis in Modern Organic Synthesis, Wiley-VCH, Weinheim, 2008.

[3] H. Gaspard-Iloughmane and C. Le Roux, "Bismuth(III) Triflate in Organic Synthesis," European Journal of Organic Chemistry, Vol. 2004, No. 12, 2004, pp. 2517-2532. doi:10.1002/ejoc.200300754

[4] R. M. Hua, "Recent Advances in Bismuth-Catalyzed Organic Synthesis," Current Organic Synthesis, Vol. 5, No. 1, 2008, pp. 1-27. doi:10.2174/157017908783497518

[5] R. M. A. Pinto, J. A. R. Salvador, C. Le Roux and J. A. Paixão, "Bismuth(III) Triflate-Catalyzed Direct Conversion of Corticosteroids into Highly Functionalized 17-Ketosteroids by Cleavage of the C17-Dihydroxyacetone Side Chain," Journal of Organic Chemistry, Vol. 74, No. 21, 2009, pp. 8488-8491. doi:10.1021/j09018478

[6] M. Bao, E. Hayashi and S. Shimada, "Cationic Organobismuth Complex with 5,6,7,12-Tetra Hydrodibenz [c,f][1,5] Azabismocine Framework and Its Coordination Complexes with Neutral Molecules," Organometallics, Vol. 26, No. 7, 2007, pp. 1816-1822.

[7] A. Miloudi, D. El-Abad, G. Boyer, J.-P., Galy and J.-P., Finet, "Synthesis, Structure and Reactivity of Triphenylbismuth Bis(2-Thiophenecarboxylate)," Main Group Metal Chemistry, Vol. 24, No. 11, 2001, pp. 767-774. doi:10.1515/MGMC.2001.24.11.767

[8] M. Chovancová, R. Jambor, A. Růžička, R. Jirásko, I. Císařová and L. Dostál, "Synthesis, Structure, and Reactivity of Intramolecularly Coordinated Organoantimony and Organobismuth Sulfides," Organometallics, Vol. 28, No. 6, 2009, pp. 1934-1941. doi:10.1021/om801194h

[9] P. Simon, F. de Proft, R. Jambor, A. Ruzicka and L. Dostál, "Monomeric Organoantimony(I) and Organobismuth(I) Compounds Stabilized by an NCN Chelating Ligand: Syntheses and Structures," Angewandte Chemie International Edition, Vol. 49, No. 32, 2010, pp. 5468-5471. doi:10.1002/anie.201002209

[10] A. Soran, H. J. Breunig, V. Lippolis, M. Arca and C. Silvestru, "Syntheses, Solid-State Structures, Solution Behavior of Hypervalent Organobismuth(III) Compounds [2- $\left.\left(\mathrm{Et}_{2} \mathrm{NCH}_{2}\right) \mathrm{C}_{6} \mathrm{H}_{4}\right]_{\mathrm{n}} \mathrm{BiX}_{3-\mathrm{n}}$ and DFT Characterization of [2- $\left.\left(\mathrm{Me}_{2} \mathrm{NCH}_{2}\right) \mathrm{C}_{6} \mathrm{H}_{4}\right]_{\mathrm{n}} \mathrm{BiX} \mathrm{X}_{3-\mathrm{n}}[\mathrm{X}=\mathrm{Cl}, \mathrm{Br}, \mathrm{I} ; \mathrm{n}=1-3]$," Journal of Organometallic Chemistry, Vol. 695, No. 6, 2010, pp. 850-862. doi:10.1016/j.jorganchem.2010.01.004

[11] A. Miloudi, D. ElAbad, G. Boyer, J.-P., Galy, J.-P., Finet and S. Didier, "Reactivity of 2-Aminothiazole and 2- or 6-Aminobenzothiazole Derivatives towards the Triphenylbismuth Diacetate/Catalytic Copper Diacetate Phenylation System," European Journal of Organic Chemistry, Vol. 2004, No. 7, 2004, pp. 1509-1516. doi:10.1002/ejoc.200300656

[12] T. Arnauld, D. H. R. Barton and E. Doris, "The Chemistry of Pentavalent Organobismuth Reagents. Part 14. Recent Advances in the Copper-Catalyzed Phenylation of Amines," Tetrahedron, Vol. 53, No. 12, 1997, pp. 41374144.

[13] E. Nonius, “CAD-4 Express Software,” Delft, 1996.

[14] Z. Otwinowski and W. Minor, "Processing of X-Ray Diffraction Data Collected in Oscillation Mode," Methods in Enzymology, Vol. 276, 1997, pp. 307-326. doi:10.1016/S0076-6879(97)76066-X

[15] L. J. Farrugia, "WinGX Suite for Small-Molecule SingleCrystal Crystallography," Journal of Applied Crystallography, Vol. 32, 1999, pp. 837-838. doi:10.1107/S0021889899006020

[16] G. M. Sheldrick, "A Short History of SHELX," Acta Crystallographica, Vol. 64, No. 1, 2008, pp. 112-122.

[17] L. J. Farrugia, "ORTEP-3 for Windows-A Version of ORTEP-III with a Graphical User Interface (GUI)," Journal of Applied Crystallography, Vol. 30, 1997, pp. 565567. doi:10.1107/S0021889897003117

[18] E. Prince and A. J. C. Wilson, "International Tables for X-ray Crystallography," 2nd Edition, Kluwer Academic Press, Boston, 1992. 